$\sqrt{B}$

J. bio-sci. 18: 34-39, 2010

ISSN 1023-8654

http://www.banglajol.info/index.php/JBS/index

\title{
ROLE OF LARGE PLASMID DNA IN SALT TOLERANCE OF A NOVEL STRAIN GRACILIBACILLUS SP. GTY
}

\author{
M Salah Uddin ${ }^{1 *}$, Zhou Jiti, M A Saleh ${ }^{1}$, A Ekram ${ }^{1}$, B Sikdar $^{1}$, S Zaman $^{1}$ \\ School of Environmental and Biological Science \& Technology, Dalian University of Technology, Dalian, China
}

\section{Abstract}

Context: Isolated plasmid DNA from salt tolerant bacteria can play an important role in special environmental conditions.

Objectives: The main objective of this study was to make a standard protocol for the isolation of large plasmid DNA from a highly salt tolerant bacterial strain, and then the plasmid DNA was eliminated from bacterial genome to know its effect on bacterial adaptation in high saline water.

Materials and Methods: The strain Gracilibacillus sp. GTY was collected from the coast line of Dalian (North China) and was inoculated in high salt concentrated bacteriological media. Wheatcroft's modified method was used to isolate plasmid DNA. Then the chemical curing agents such as acridine orange, SDS, sodium benzoate and mitomycin $C$ were applied separately in different concentrations to eliminate plasmid DNA. After the elimination of plasmid DNA, the strain was cultivated in the MS liquid media containing $5 \%, 15 \%$ and $25 \%(\mathrm{w} / \mathrm{v})$ of $\mathrm{NaCl}$ respectively and their growth rates were compared with the non-eliminated culture.

Results: According to Wheatcroft's modified method, the plasmid took two more hours to get isolated from the chromosomal DNA and the approximate size of the extracted plasmid DNA was $23.13 \mathrm{~kb}$. Among all of the curing agents, plasmid DNA was eliminated successfully by acridine orange after $24 \mathrm{~h}$ of treatment at the concentration of $50 \mathrm{mg} / \mathrm{l}$. Growth rates of plasmid eliminated culture were lower than non-eliminated culture and the growth rates of the plasmid eliminated culture were decreasing significantly with the addition of more $\mathrm{NaCl}$.

Conclusion: The results obtained in this study suggest that the presence of large plasmid DNA in salt tolerant bacteria is related to their survival strategies. The genes located in the large plasmids may encode important traits related to their adaptation to special environmental conditions.

Keywords: Salt tolerance, halophilic bacteria, curing agent, extrachromosomal DNA, Gracilibacillus sp. GTY.

\section{Introduction}

Most of the halophilic bacteria have a strict sodium requirement. Some of them are highly salt tolerant, able to grow in the media containing $1-20 \%$ (w/v) $\mathrm{NaCl}$ (Carrasco et al. 2005). A considerable number of these bacteria contain large molecules of extrachromosomal DNA. Bacterial plasmids contain genes that codes for additional traits such as plant tumor induction and $\mathrm{CO}_{2}$ fixation (Schaferjohann et al. 1995), antibiotic and heavy metal resistance (Taghavi et al. 1997), root nodulation and nitrogen fixation (Barloy-Hubler et al. 2000), virulence, conjugation and different metabolic transformation (Krum and Ensing 2001, Nojiri et al. 2001). The present study was conducted with a recently characterized highly salt tolerant bacterium Gracilibacillus sp. GTY which is able to grow up to $2-25 \%$ (w/v) of $\mathrm{NaCl}$ concentrated media.

Like the other bacterial strains, Gracilibacillus sp. GTY also harbors a large molecule of plasmid DNA. During the period of genetic and molecular study, the presence of this extrachromosomal DNA was discovered. Usually, the detection of large plasmids is not easy because most plasmid manipulations are carried out with extraction procedures based on disruptive techniques that permit a reliable extraction of small or moderately large plasmids ranging from $1.5 \mathrm{~kb}-20 \mathrm{~kb}$.

Elimination of native plasmids is usually an essential step in their functional analysis. Various physical and chemical methods have previously been developed and used for elimination of plasmids. Therefore, this

\footnotetext{
${ }^{1}$ Department of Genetic Engineering and Biotechnology, University of Rajshahi, Rajshahi-6205, Bangladesh

* Corresponding author E-mail: salimench@yahoo.com
} 
study was taken firstly to study the isolation technique of the plasmid DNA and furthermore, elimination of the plasmid DNA from the bacterial genome to know its role in bacterial salt tolerance.

\section{Materials and Methods}

Bacterial strain: Gracilibacillus sp. GTY was collected from the Dalian costal area, Northern China as a mixed bacterial culture. Then its single colony was isolated and acclimatized in high salt containing Laurel Broth (LB) liquid media. The strain was identified on the basis of morphological and physio-biochemical characteristics and 16S rDNA sequence analysis, and was deposited as patent strain in China General Microorganism Culture Center with the accession number CGMCC 1527. The 16S rDNA sequence of the strain GTY was also submitted to GenBank with the number DQ 286727. It is gram positive, rod-shaped and strictly aerobic, resistance to the antibiotics, streptomycine and canamycine. The strain is completely colonized and forms white unique colonies around the agar plate.

Culture conditions: The strain was cultured in Mineral Salt (MS) liquid media to set up our present experiment. The MS media contained $1 \mathrm{~g} / \mathrm{l}$ of $\left(\mathrm{NH}_{4}\right)_{2} \mathrm{SO}_{4}, 1.4 \mathrm{~g} / \mathrm{l}$ of $\mathrm{K}_{2} \mathrm{HPO}_{4}, 0.6 \mathrm{~g} / \mathrm{l}$ of $\mathrm{KH}_{2} \mathrm{PO}_{4}, 1 \mathrm{~g} / \mathrm{l}$ of $\mathrm{MgSO}_{4}, 0.1 \mathrm{~g} / \mathrm{l}$ of $\mathrm{CaCl}_{2}, 0.1 \mathrm{~g} / \mathrm{l}$ of $\mathrm{FeSO}_{4}, 2-25 \%$ (w/v) NaCl and $10 \mathrm{~g} / /$ of proline as carbon source. The media incubated at $30^{\circ} \mathrm{C}$ on a rotary shaker at $150 \mathrm{r} / \mathrm{min}$ and a standard $\mathrm{pH}$ was maintained 7.2.

Isolation technique of the plasmid DNA: Some serious problems were faced during the isolation period of this plasmid DNA from the bacterial genome. Several methods were assayed, with varying degrees of success. Finally, the method described by Wheatcroft et al. (1990) was decided to use with some modifications. The isolation technique was partially similar with the work of Montserrat et al. (2003) also, where megaplasmids were isolated from the moderately halophilic bacteria. Bacterial strain was harvested in a standard (15\% w/v) $\mathrm{NaCl}$ concentrated MS liquid media and was incubated over night. One $\mathrm{ml}$ of this sample was taken in a centrifuge tube and centrifuged at $13000 \mathrm{rpm}$ for $5 \mathrm{~min}$ to harvest the bacterial cells. The cells were then resuspended in $500 \mu \mathrm{l}$ of $5 \%(\mathrm{w} / \mathrm{v})$ salt solution at $4^{\circ} \mathrm{C}$. The cells were diluted in the salt solution by a dilution machine. One $\mathrm{ml}$ of $0.3 \%(\mathrm{w} / \mathrm{v})$ sodium lauryl sarcosinate $\left(4^{\circ} \mathrm{C}\right)$ was added slowly and mixed gently (to avoid a premature cell disruption) before centrifuging at $13000 \mathrm{rpm}$ for $3 \mathrm{~min}$ at $4^{\circ} \mathrm{C}$. The supernatant was removed

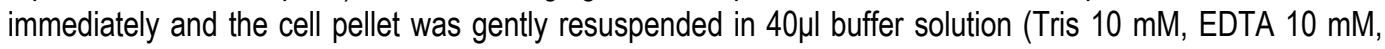
$20 \%$ w/v Ficoll 400000 ) and the sample tube left for $1 \mathrm{~h}$ in ice.

Agarose gel electrophoresis was performed using $0.60 \%$ (w/v) agarose (Solarbio). Agarose was melted in 1×TBE buffer ( $0.5 \times: 0.045 \mathrm{~mol} / \mathrm{l}$ Tris-boracic acid, $0.001 \mathrm{~mol} / / \mathrm{EDTA})$ and mixed well before pouring. The gel was stained with ethidium bromide for 2-3 min. The electrophoresis tank was leveled off with $1 \times \operatorname{TBE}\left(4^{\circ} \mathrm{C}\right)$ buffer until it was covering the gel, and then the $5 \mu$ samples mixed with three different lytic solutions loaded in the three wells separately. The samples were mixed (1:1) with 10xloading buffer, lytic solution ( $230 \mu$ l of Tris-HCL, $10 \mathrm{mM}$ EDTA, $10 \mathrm{mM}$ RNase $(0.4 \mathrm{mg} / \mathrm{ml})$, xylene cyanol $(1 \mathrm{mg} / \mathrm{ml})$ mixed with $25 \mu \mathrm{l}$ of lysozyme $(10 \mathrm{mg} / \mathrm{ml}))$ and $1 \%(\mathrm{w} / \mathrm{v})$ xylene cyanol respectively. Electrophoresis was carried out in a refrigerator at $4^{\circ} \mathrm{C}$ with the tank submerged in ice. The samples and DNA markers were left to run for $2 \mathrm{~h}$ at $100 \mathrm{~V}$.

Elimination technique of the Plasmid DNA: Bacterial strain was inoculated in a standard $(15 \% \mathrm{w} / \mathrm{v}) \mathrm{NaCl}$ concentrated MS liquid media and was incubated at $30^{\circ} \mathrm{C}$ on a rotary shaker at $150 \mathrm{r} / \mathrm{min}$ for $12 \mathrm{~h}$. Then the chemical curing agents such as acridine orange (Northern China Specific Chemical Co. Ltd.), SDS (Solarbio), sodium benzoate (Tianjin Kermel Chemical Reagents Development Centre, China) and Mitomycin $\mathrm{C}$ (Solarbio) were applied separately in different concentrations to treat the bacterial strain for $24 \mathrm{~h}$. Then the strain was transferred immediately in to the four new conical flasks containing $15 \%(\mathrm{w} / \mathrm{v}) \mathrm{NaCl}$ concentrated MS media to avoid the chemical effects. Several generations were maintained in the same way. The elimination of plasmid DNA was tested by agarose gel electrophoresis method. After successful elimination 
of plasmid DNA, the treated bacteria were again cultivated separately in the MS liquid media containing $5 \%$, $15 \%$ and $25 \%$ (w/v) NaCl and their growth rates were observed.

Estimation: DNA marker DL2000 and $\lambda$-Hind III digest (TaKaRa Biotechnology Co., Ltd.) were used to determine the approximate size of the isolated plasmid bands. We estimated the molecular size of the bands with the Quantity One program of the Video camera and Imaging system. Bacterial growth rates were observed by its $\lambda \max$ value (660) using an UV-visible spectrophotometer (JASCO, V-560, UV/VS spectrophotometer), and all the assays were performed in duplicate.

\section{Results}

Isolation of the plasmid DNA: According to Wheatcroft et al. (1990) modified method, this plasmid took two more hours to get isolated from the chromosomal DNA and the approximate size of the extracted plasmid DNA was $23130 \mathrm{bp}(23.13 \mathrm{~kb})$. At first, the sample was loaded with10xloading buffer (Fig. 1) and then the samples was also loaded with lytic solution and $1 \%(\mathrm{w} / \mathrm{v})$ xylene cyanol separately to obtain comparatively better results (Fig. 2). But from all these cases, almost the same results were obtained.

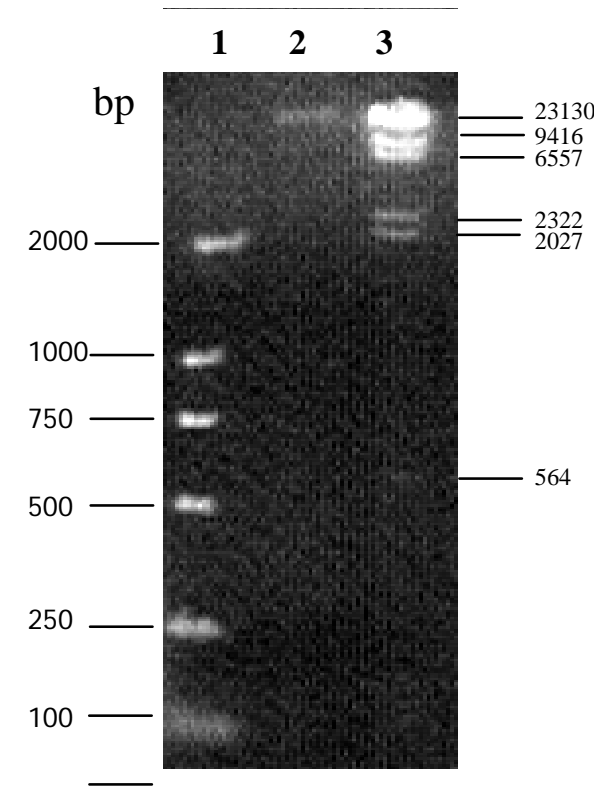

Fig. 1. Plasmid profiles observed in the strain GTY, lanes $M_{1}$ and $\mathrm{M}_{2}$ show DNA markers DL2000 and $\lambda$-Hind III digest respectively. Lane 2 shows approximate size (23130 bp) of the plasmid DNA loaded with 10xloading buffer.

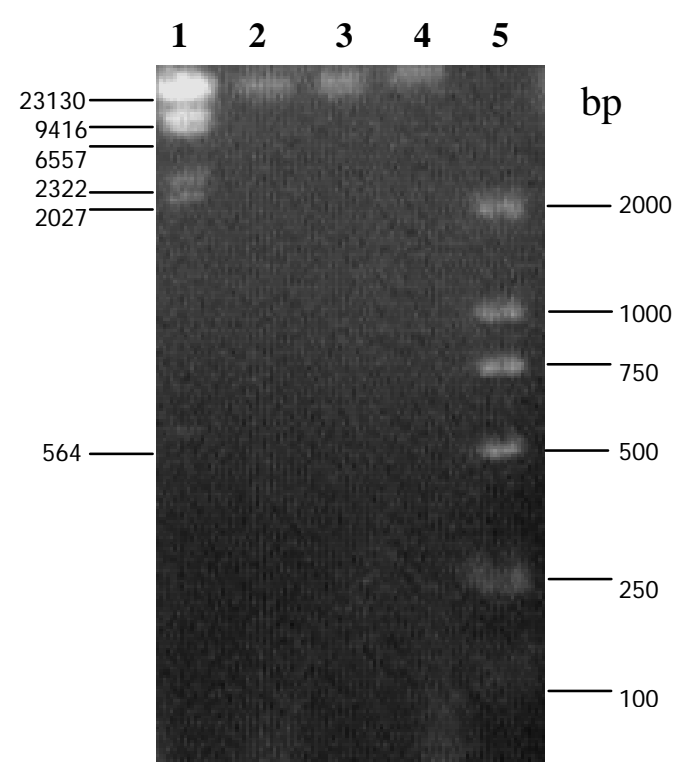

Fig. 2. Plasmid profiles observed in the strain GTY, Lane 1 and 5 show DNA markers DL2000 and $\lambda$-Hind III digest respectively. Lane 2-4 show comparative plasmid bands loaded with $10 \times$ loading buffer, lytic solution and $1 \%(\mathrm{w} / \mathrm{v})$ of xylene cyanol respectively.

Table 1. Effect of different chemical agents on the elimination of the plasmid DNA

\begin{tabular}{lccc}
\hline Eliminating agents & Concentrations & Treatment period $(\mathrm{h})$ & Elimination rate $(\%)$ \\
\hline Acridine orange & $50 \mathrm{mg} / \mathrm{l}$ & 24 & 100 \\
SDS & $2 \%(\mathrm{w} / \mathrm{v})$ & 24 & 0 \\
Sodium benzoate & $2 \%(\mathrm{w} / \mathrm{v})$ & 24 & 0 \\
Mitomycin C & $2 \mathrm{mg} / \mathrm{l}$ & 24 & 0 \\
\hline
\end{tabular}

Elimination of the plasmid DNA: Bacterial strain was treated with all four eliminating agents separately to know their plasmid eliminating activities and the observations were taken place at different time intervals. 
The agents were used in different concentrations. Among all of these agents, plasmid DNA was eliminated successfully by acridine orange after $24 \mathrm{~h}$ of treatment at the concentration of $50 \mathrm{mg} / \mathrm{l}$. On the other hand, rest of the three agents could not produce any remarkable plasmid loss in this experiment (Table 1). Plasmid DNA damaging was analyzed by gel electrophoresis technique at different time of observations. Samples were loaded with 10xloading buffer only. Several generations were considered for this experiment to observe the complete plasmid loss in the strain (Fig. 3).

Effect of the plasmid DNA on host bacterial salt tolerance: Growth rates of plasmid eliminated culture were lower than non-eliminated culture (Fig. 4) and the growth rates of the plasmid eliminated culture were decreasing significantly with the addition of $\mathrm{NaCl}$ (Figs. 5, 6).

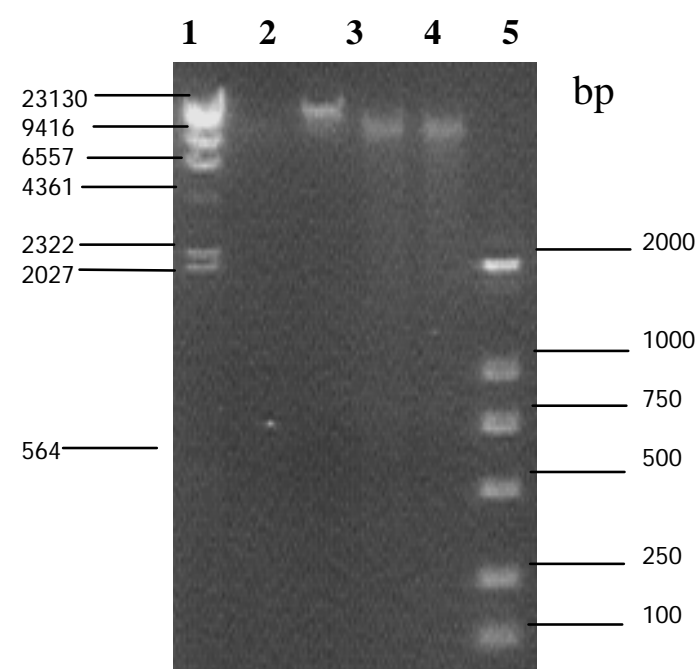

Fig. 3. Observation of plasmid DNA damaging from the gel electrophoresis. Gel electrophoresis was carried out after $24 \mathrm{~h}$ of treatment. Lane 1 and 6 show DNA markers DL2000 and $\lambda$-Hind III digest respectively. Plasmid missing is observed in the lane 2 where sample was treated with acridine orange. No plasmid missing is observed in the lane 3-5 where samples were treated with SDS, sodium benzoate and mitomycin $\mathrm{C}$ respectively.

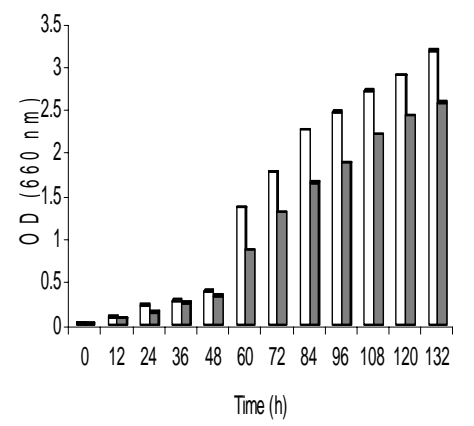

Fig. 5. Comparative growth rates of plasmid eliminated ( $(\boldsymbol{)})$ and non-eliminated ( $\square$ ) cultures in MS liquid media containing $15 \%$ w/v of $\mathrm{NaCl}$.

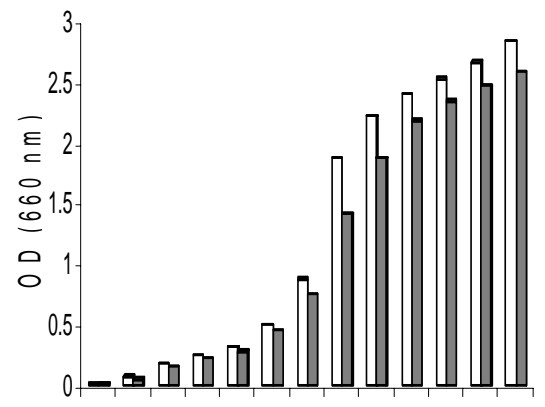

$0122436486072 \quad 8496108120132144$

Time (h)
Fig. 4. Comparative growth rates of plasmid eliminated ( $\mathbf{\square})$ and non-eliminated ( $\square$ ) cultures in MS liquid media containing $5 \%$ $w / v$ of $\mathrm{NaCl}$.

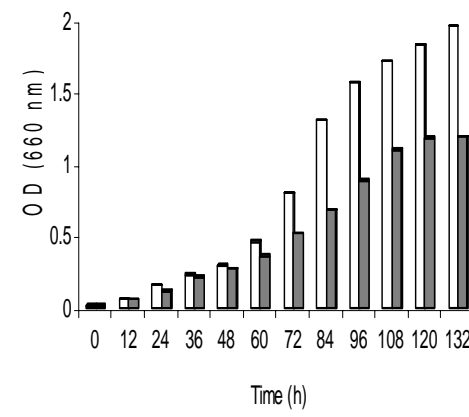

Fig. 6. Comparative growth rates of plasmid eliminated ( $(\bullet)$ and non-eliminated ( $\square$ ) cultures in MS liquid media containing $25 \% \mathrm{w} / \mathrm{v}$ of $\mathrm{NaCl}$. 


\section{Discussion}

Large plasmid DNA cannot be separated readily from the chromosomal DNA by normal gel electrophoresis method. Serious technological challenges are often faced to isolate large plasmid DNA (Sobral et al. 1991, Currier and Nester 1976). They are closed-circular supercoiled and move very slowly into the gels. In some cases, plasmid bands can be visualized only and then bands can be dissected from the gel. But in this experiment, the plasmid bands were recovered and purified successfully.

There are no standard protocols applicable to all kind of plasmids. The usefulness of plasmid eliminating agents is still unpredictable in many bacterial strains. There are some physical and chemical protocols of plasmid elimination have been established and some methods that have provided good results with certain species. Hooper et al. (1984) reported earlier the successful plasmid elimination by novobiocin in Escherichia coli. Elimination of plasmids using acridine orange has also been reported by many reporters (Riva et al. 1973, Nakamura et al. 1975, Toshio et al. 1982, Viola et al. 2004). But in all cases, they could eliminate some small sized plasmids and elimination rates were not satisfactory. In the present experiment, a large sized plasmid DNA was eliminated successfully within $24 \mathrm{~h}$ and elimination rate was $100 \%$. SDS, sodium benzoate, mitomycin $\mathrm{C}$ and ethidium bromide are used as curing agents in many species. But they could not produce plasmid loss in this experiment. Radiation is also effective to damage plasmid and chromosomal DNA in many species. Large plasmids in the salt tolerant bacteria often control some of their ecological traits. These plasmids can represent 10\%-20\% of genetic material (Bret Barton et al. 1995).

According to Goldmann et al. (1991), Rhizobium meliloti can use alfa-synthesized betaines as osmoprotactants and source of energy, and genes involved in the catabolism are located on pSym in RCR2011 plasmid. There are many other evidences available in the literatures that plasmid genes often code the additional traits for the microorganisms as well as higher plants and animals. The results obtained from this experiment suggest that genes located in the isolated large plasmid might be responsible for the production of its compatible solute-proline. Therefore, plasmid eliminated strain lost its normal growth ability in the media containing high concentrations of $\mathrm{NaCl}$.

\section{Conclusion}

The large plasmid DNA $(23.13 \mathrm{~kb}$ ) was isolated by a modified method. The plasmid DNA was successfully eliminated by acridine orange in a treatment period of $24 \mathrm{~h}$. Growth rates of plasmid eliminated cultures were reduced remarkably under high salt concentration conditions. Based on the above facts, it is easily realizable here that the presence of large plasmids in halotolerant bacteria are related to their survival strategies. Genes located in this large plasmid DNA encode important traits related to their adaptation to special environmental conditions.

\section{Acknowledgements}

We are grateful to the Chinese Ministry of Education for the financial support of this study. We also thank Professor Zhou Jiti for his scientific and technical advice and providing us the laboratory facility.

\section{References}

Barloy-Hubler F, Capela D, Barnett M, Kalman S, Federspiel NA, Long SR, Galibert F. 2000. High-resulution physical map of the Sinorhizobium meliloti 1021 pSyma megaplasmid. J Bacteriol 182, 1185-1189. http://dx.doi:10.1128/JB.182.4.1185-1189.2000 PMid:10648551 PMCid:94401.

Bret Barton M, Gordon Harding P, Anthony Zuccarelli J. 1995. A general method for detecting and sizing large plasmids. Anal Biochem 226, 235-240. http://dx.doi:10.1006/abio.1995.1220 PMid:7793624 
Carrasco IJ, Márquez MC, Yanfen X, Ma Y, Cowan DA, Jones BE, Grant WD, Ventosa A. 2005. Gracilibacillus orientalis sp. nov., a novel moderately halophilic bacterium isolated from a salt lake in Inner Mongolia, China. IJSEM 56, doi:509604.10.1099/ijs.0.63971-0

Currier TC, Nester EW. 1976. Isolation of covalently closed circular DNA of high molecular weight from bacteria. Anal Biochem 76, 431441. http://dx.doi:10.1016/0003-2697(76)90338-9

Goldmann A, Boivin C, Fleury V, Message B, Lecoeur L, Maille M, Tepfer D. 1991. Betaine use by rhizosphere bacteria: Genes essential for trigonelline, stachydrine, and carnitine catabolism in Rhizobium meliloti are located on pSym in the symbiotic region. MPMI 4, 571-578. http://dx.doi:10.1094/MPMl-4-571 PMid:1804402

Hooper C, John Wolfson S, Gail McHugh L, Mark Swartz D, Charlotte Tung, Morton Swartz N. 1984. Elimination of plasmid pMG110 from Escherichia coli by Novobiocin and other inhibitors of DNA Gyrase. AAC 25, 586-590.

Krum JG, Ensign SA. 2001. Evidence that a linear megaplasmid encodes enzymes of aliphatic alkene and epoxide metabolism and coenzyme M (2-mercaptoethanesulfonate) biosyanthesis in Xanthobacter strain Py2. J Bacteriol 183, 2172-2177. http://dx.doi:10.1128/JB.183.7.2172-2177.2001 PMid:11244054 PMCid:95121

Montserrat A, Fernando M, Inmaculada L, Emilla Q, Ana del M. 2003. Megaplasmids in Gram-nagative, moderately halophilic bacteria. FEMS Microbiol 227, 81-86.

Nakamura H, Saganuma A, Greenberg J. 1975. Effect of inorganic phosphate on acridine inhibition and plasmid curing in Escherichia coli. J Gen Microbiol 91, 45-52. PMid:466

Nojiri H, Sekiguchi H, Maed aK, Urata M, Nakai S, Yoshida T, Habe H, Omori T. 2001. Genetic characterization and evolutionary implications of a car gene cluster in the carbazole degrader Pseudomonas sp. Strain CA10.TJ Bacteriol 183, 3663-3679.

Riva S, Fietta A, Berti M, Silvestri G, Romero E. 1973. Relationships Between Curing of the F Episome by Rifampin and by Acridine Orange in Escherichia coli. AAC 3(4), 456-462.

Schaferjohann J, Yoo JG, Bowien B. 1995. Analysis of the genes forming the distal parts of the two $\mathrm{cbb} \mathrm{CO}_{2}$ fixation operons from Alcaligenes eutrophus. Arch Microbiol 163, 291-299. http://dx.doi:10.1007/BF00393383

Sobral BWS, Honeycutt RJ, Atherly AG, Mcclelland M. 1991. Electrophoretic separation of all three replicons from Rhizobium meliloti. J Bacteriol 173, 5173-5180.

Taghavi S, Mergeay M, Van der Lelie D. 1997. Genetic and physical map of the Alcaligenes eutrophus CH34 megaplasmid pMOL28 and it derivative pMOL50 obtained after temperature induced mutagenesis and mortality. Plasmid 37, 22-34. http://dx.doi:10.1006/plas.1996.1274 PMid:9073579

Toshio H, Andrea A, Yusaku F, Seinosuke U. 1982. Elimination of Plasmid-Linked Polyglutamate Production by Bacillus subtilis (natto) with Acridine Orange. AEM 44, 1456-1458.

Viola G, Facciolo L, Dall_Acqua S, Di Lisa F, Canton M, Vedaldi D, Fravolini A, Tabarrini O, Cecchetti V. 2004. 6-Aminoquinolones: photostability, cellular distribution and phototoxicity. TiV 18, 581-592.

Wheatcroft R, McRae DG, Miller RW. 1990. Changes in the Rhizobium meliloti genome and the ability to detect supercoiled plasmids during bacteriod development. Mol Plant Microbe Interact 3, 9-17. http://dx.doi:10.1094/MPMI-3-009 